\title{
Increased Testicular Insulin-like Growth Factor 1 is Associated with Gonadal Activation by Recombinant Growth Hormone in Immature Rats
}

\section{Yang Xu}

Hanyang University College of Natural Science

Chang Yong Han

Hanyang University College of Natural Science

Mi Jung Park

Inje University Sanggye Paik Hospital

Myung Chan Gye ( $\nabla$ mcgye@hanyang.ac.kr)

Hanyang University College of Natural Science https://orcid.org/0000-0001-5682-3709

\section{Research Article}

Keywords: Recombinant human growth hormone, Spermatogenesis, Steroidogenesis, Insulin-like growth factor-1, Kisspeptin, Gonadotropin-releasing hormone, Rats

Posted Date: August 27th, 2021

DOl: https://doi.org/10.21203/rs.3.rs-829382/v1

License: (9) This work is licensed under a Creative Commons Attribution 4.0 International License. Read Full License 


\section{Abstract}

To understand the mechanism of precocious sexual maturation following prepubertal growth hormone $(\mathrm{GH})$ therapy, the effects of recombinant human $\mathrm{GH}(\mathrm{rhGH})$ on the kisspeptin-gonadotropin-releasing hormone-luteinizing hormone (GnRH-LH) system in the hypothalamus-pituitary axis, systemic and testicular insulin-like growth factor-1 (IGF1), spermatogenesis and Leydig cell steroidogenesis, and circulating testosterone levels were examined in immature rats. Following daily injection of rhGH (1 or 2 $\mathrm{IU} / \mathrm{kg}$ ) from postnatal day (PND) 21 to PND 23 or 30, testicular steroidogenic pathway genes and spermatogenesis marker genes mRNA levels, the number and size of HSD17B(+) Leydig cells, and blood testosterone levels in the rhGH rats were significantly higher than those of controls on PNDs 24 and 31. Hypothalamic Kiss1 and Gnrh1 mRNA in the rhGH rats were significantly higher than those in the controls on PND 24, indicating early activation of hypothalamic kisspeptin-GnRH neurons by rhGH. Hypothalamic Igf1 mRNA levels in rhGH rats were significantly higher than those in the controls on PND 24 but significantly lower than those in controls on PND 31. Testicular Igf1 mRNA levels were significantly higher in rhGH rats than in the controls on PNDs 24 and 31 whereas liver Igf1 mRNA levels and circulating IGF1 levels were not. In progenitor Leydig cells, rhGH significantly increased the Igf1 and steroidogenic pathway genes mRNA levels and the testosterone production. Therefore, local increases in testicular IGF1 might be an important mediator of gonadal activation via steroidogenic activation of Leydig cells in immature rats given rhGH.

\section{Introduction}

Puberty is initiated by the activation of the hypothalamus-pituitary-gonad axis (HPG axis). In the hypothalamus, kisspeptin activates gonadotropin-releasing hormone $(\mathrm{GnRH})$ secretion, resulting in luteinizing hormone (LH) secretion in the pituitary gland, steroidogenesis and gametogenesis in the gonads, and the onset of puberty (Navarro et al., 2004; Tena-Sempere, 2006; Huh et al., 2021). As a neuromodulator, kisspeptin not only conveys the modulatory actions of sex steroids to GnRH neurons but also directly stimulates LH secretion in the pituitary gland (Smith, 2008; Skorupskaite et al., 2014). Growth hormone $(\mathrm{GH})$ has been shown to play a role in the onset of puberty, and it regulates the expression of steroidogenic acute regulatory protein and steroidogenesis in progenitor Leydig cells (Kanzaki \& Morris, 1999). GH-receptor knockout mice and GH-deficient mice show delayed puberty (Chandrashekar et al., 2001; Keene et al., 2002). GH therapy normalizes the progression of puberty in GHdeficient mice (Darendelier et al., 1990; Stanhope et al., 1992). Most of the physiologic effects of GH on puberty have been explained by the actions of insulin-like growth factor-1 (IGF1) (Roith et al., 2001; Christoforidis et al., 2005; Ipsa et al., 2019). IGF1 is primarily produced in the liver, but it is also synthesized by almost all tissues, including the testes (Rosen, 1999; Cannarella et al., 2018). In mammals, including humans, circulating IGF1 levels increase at the onset of puberty, and the administration of IGF1 advances the process of puberty (Hiney et al., 1996; Chang et al., 2018). In Laron syndrome patients, who have congenital IGF1 deficiency, the administration of IGF1 restores sexual maturation (Laron \& Klinger, 1998). In immature animals, IGF1 can activate the brain-gonadal axis and 
contributes to the timing of puberty in males and females by affecting $\mathrm{GnRH}$ neurons and possibly kisspeptin neurons in the hypothalamus (Hiney et al., 1991; Wolfe et al., 2014).

Recombinant human growth hormone (rhGH) therapy has been introduced as a treatment for a variety of conditions associated with short stature, such as GH deficiency, Turner syndrome, chronic renal failure, short-stature homeobox gene, and Noonan syndrome (Blum et al., 2007; Romano et al., 2009). However, there are concerns that it can induce skeletal maturation and the early onset of puberty, though some studies have reported that rhGH therapy did not correlate with early puberty onset (Kamp et al., 2002; Crowe et al., 2006; Huh et al., 2021). To understand the mechanism by which rhGH could stimulate the early onset of puberty in males, changes in hypothalamic kisspeptin, GnRH and IGF1 levels, pituitary and circulating LH, spermatogenesis, testicular steroidogenesis, and IGF1 in the circulation, liver, and testes were examined in immature rats following prepubertal rhGH treatment.

\section{Materials And Methods}

\subsection{Animals and tissue sampling}

Immature male rats (Sprague Dawley) were purchased on their postnatal day (PND) 14 from Daehan Biolink (Deajeon, Korea) and maintained on a 12:12-hrs light/dark cycle with food and water available ad libitum (lights on at 8:00 a.m.). The animals were randomized into three groups and subcutaneously injected with rhGH ( 1 or $2 \mathrm{IU} / \mathrm{kg}$ ) or $0.1 \mathrm{~mL}$ of saline every morning at 11 a.m. from PND 21 to PND 23 or 30. The rats were sacrificed by $\mathrm{CO}_{2}$ asphyxiation on PND 24 or 31 . Blood was collected by cardiac puncture and prepared for serum. The testes, epididymis, prostate, preputial glands, seminal vesicle, and brain were dissected and weighed. The hypothalamus and pituitary gland were further dissected from the brain. Organs were subjected to histological and gene-expression analyses.

\subsection{Real-time reverse transcription-polymerase chain reaction (RT-qPCR)}

All tissues were frozen in liquid nitrogen and then subjected to total RNA extraction using TRI reagent (Molecular Research Center, Cincinnati, $\mathrm{OH}$ ). RNA samples $(1 \mu \mathrm{g})$ were reverse transcribed for $60 \mathrm{~min}$ at $42^{\circ} \mathrm{C}$ in a $20 \mu \mathrm{L}$ reaction with ReverTra Ace ${ }^{\circledR}$ qPCR RT Master Mix (Toyobo, Osaka, Japan). In the testes, steroidogenic pathway genes, spermatogenesis marker genes (Transition protein 1, Tnp 1; Transition protein 2, Tnp2; Protamine, Prm), and Igf1 were analyzed by RT-qPCR. In the hypothalamus and pituitary gland, Igf1, KiSS-1 Metastasis Suppressor(Kiss1), gonadotropin Releasing Hormone 1 (Gnrh1), and luteinizing hormone beta polypeptide ( $L h b)$ mRNA levels were analyzed. Ribosomal protein $L 7(R p / 7)$ was used as an endogenous control. The primer sequences and PCR conditions are summarized in Table 1. RT-qPCR was performed using an SYBR Premix EX Taq kit according to the manufacturer's instructions (Takara, Shiga, Japan) in a My-iQ real-time PCR detection system (Bio-rad Laboratories, Hercules, CA). Relative mRNA levels were calculated using the comparative $2^{-\Delta \Delta C t}$ method (Livak \& Schmittgen, 2001). 
Table 1

Primer sequences used in RT-qPCR analyses

\begin{tabular}{|c|c|c|c|c|c|}
\hline Genes & \multicolumn{2}{|c|}{ Primer sequences $\left(5^{\prime}-3^{\prime}\right)$} & Size & Ann. temp. & GenBank ID \\
\hline \multirow[t]{2}{*}{$\operatorname{lgf1}$} & $\mathrm{F}$ & tacctggcactctgcttgct & \multirow[t]{2}{*}{194} & \multirow[t]{2}{*}{64} & \multirow[t]{2}{*}{ NM_001082477 } \\
\hline & $\mathrm{R}$ & cggaagcaacactcatccac & & & \\
\hline \multirow[t]{2}{*}{ Lhcgr } & $\mathrm{F}$ & ctcacctatctccctgtcaa & \multirow[t]{2}{*}{365} & \multirow[t]{2}{*}{64} & \multirow[t]{2}{*}{ NM_012978 } \\
\hline & $\mathrm{R}$ & acagactcgttattcatccc & & & \\
\hline \multirow[t]{2}{*}{ Sf1 } & $\mathrm{F}$ & cgccaggagtttgtctgtct & \multirow[t]{2}{*}{185} & \multirow[t]{2}{*}{67} & \multirow[t]{2}{*}{ NM_001191099 } \\
\hline & $\mathrm{R}$ & acctccaccaggcacaatag & & & \\
\hline \multirow[t]{2}{*}{ Star } & $\mathrm{F}$ & aaccaggaaggctggaagaa & \multirow[t]{2}{*}{123} & \multirow[t]{2}{*}{64} & \multirow[t]{2}{*}{ NM_031558.3 } \\
\hline & $\mathrm{R}$ & tctgtccatgggctggtcta & & & \\
\hline \multirow[t]{2}{*}{ Сур11a1 } & $\mathrm{F}$ & ttgcctttgagtccatcacc & \multirow[t]{2}{*}{187} & \multirow[t]{2}{*}{64} & \multirow[t]{2}{*}{ NM_017286.2 } \\
\hline & $\mathrm{R}$ & gcatggtccttccaggtctt & & & \\
\hline \multirow[t]{2}{*}{ Сур17a1 } & $\mathrm{F}$ & aacgttgactccagcattgg & \multirow[t]{2}{*}{163} & \multirow[t]{2}{*}{60} & \multirow[t]{2}{*}{ NM_012753.2 } \\
\hline & $\mathrm{R}$ & gcgtgggtgtaatgagatgg & & & \\
\hline \multirow[t]{2}{*}{$H s d 3 b 1$} & $\mathrm{~F}$ & gcattaaccccactcccact & \multirow[t]{2}{*}{146} & \multirow[t]{2}{*}{60} & \multirow[t]{2}{*}{ NM_001007719.3 } \\
\hline & $\mathrm{R}$ & ggaccctgacctccttcaga & & & \\
\hline \multirow[t]{2}{*}{ Hsd17b3 } & $\mathrm{F}$ & gtccctggcctctttacagc & \multirow[t]{2}{*}{191} & \multirow[t]{2}{*}{64} & NM_008291 \\
\hline & $\mathrm{R}$ & tttaacaaactcatcggcgg & & & \\
\hline Сур19a1 & $\mathrm{F}$ & tatccggaggtggaaacagc & 181 & 60 & NM_017085 \\
\hline & $\mathrm{R}$ & cgtcaatcacgtcatcctcc & & & \\
\hline Tnp1 & $\mathrm{F}$ & gatgcaagtcgcaattaccg & 184 & 67 & NM_017056.2 \\
\hline & $\mathrm{R}$ & ccgaatttcgtcacaactgg & & & \\
\hline Tnp2 & $\mathrm{F}$ & gaagaccttggaagggaaagtg & 150 & 64 & NM_017057.2 \\
\hline & $\mathrm{R}$ & tggctatctccttttgggat & & & \\
\hline Prm2 & $\mathrm{F}$ & tatgggaggacagaaagggg & 157 & 58 & NM_012873 \\
\hline & $\mathrm{R}$ & tcctccttcgggatcttctg & & & \\
\hline Kiss1 & $\mathrm{F}$ & agctgctgcttctcctctgt & 152 & 64 & NM_181692 \\
\hline & $\mathrm{R}$ & aggcttgctctctgcatacc & & & \\
\hline Gnrh1 & $\mathrm{F}$ & ccgctgttgttctgttgact & 150 & 64 & NM_012767 \\
\hline
\end{tabular}




\begin{tabular}{|c|c|c|c|c|}
\hline Genes & Primer sequences $\left(5^{\prime}-3^{\prime}\right)$ & Size & Ann. temp. & GenBank ID \\
\hline & R ggggttctgccatttgatcc & & & \\
\hline \multirow[t]{2}{*}{ Lhb } & F tcccaggactcaaccaatga & 112 & 60 & NM_001082477 \\
\hline & R tggttagaacacctgctggc & & & \\
\hline \multirow[t]{2}{*}{ Rp/7 } & F tcaatggagtaagcccaaag & 246 & 60 & NM_011291 \\
\hline & $\mathrm{R}$ caagagaccgagcaatcaag & & & \\
\hline
\end{tabular}

Dissected testes were fixed in Bouin's solution (HT10132, Sigma-Aldrich, St. Louis, MO) for 12 hrs. After dehydration, the tissues were cleared with xylene and embedded in Paraplast (Leica Biosystems, Wetzlar, Germany). Sections ( $5 \mu \mathrm{m}$ thick) were placed on slides coated with poly-L-lysine (P2658, Sigma-Aldrich). After deparaffinization and rehydration, hematoxylin and eosin staining were conducted. Microscopic observation and photography were conducted using a microscope equipped with a digital camera system (IX71; Olympus, Tokyo, Japan). Image analyses of the seminiferous tubule diameter and luminal epithelial area were conducted using an image-analysis program (IMT iSolution Lite, version 7.8; iMTechnology, Bucheon-si, Korea). At least eight testes at each rhGH dosage and more than 10 seminiferous tubules per testis were measured to determine the seminiferous tubule diameter and luminal area.

\subsection{Immunohistochemical analysis of HSD17B in testes from PND 24}

Immunohistochemical labeling of $17 \beta$-hydroxysteroid dehydrogenase (HSD17B) was conducted in the testes of rhGH-injected rats. Briefly, Bouin's solution-fixed testes slides were coated with poly-L-lysine. After deparaffinization and rehydration, the slides were blocked by incubation with $1 \%$ rabbit serum in phosphate buffered saline (PBS) and incubated with rabbit anti-HSD17B antibody (sc-31620, Santa Cruz Biotechnology, Dallas, TX) diluted to $4 \mu \mathrm{g} / \mathrm{mL}$ in $1 \%$ rabbit serum in PBS in a humidified chamber overnight at $4^{\circ} \mathrm{C}$. In the negative control, normal rabbit IgG (ab172730, Abcam, Cambridge, UK) diluted to $4 \mu \mathrm{g} / \mathrm{mL}$ in $1 \%$ rabbit serum in PBS was used instead of the primary antibodies. After washing in PBS, horseradish peroxidase-conjugated goat anti-rabbit IgG (ab175470, Abcam) diluted 1:200 in 1\% rabbit serum in PBS was applied, and the slides were incubated for $30 \mathrm{~min}$ at room temperature. After being washed in PBS, the slides were stained with hematoxylin and eosin, mounted with Canada balsam (03984, Sigma-Aldrich), and observed with an epifluorescence microscope (IX71, Olympus, Tokyo, Japan) equipped with a digital imaging system (DP71, Olympus).

\subsection{Immunofluorescence of HSD3B in rhGH-treated rats' testes}


Paraformaldehyde (PFA, 4\%)-fixed testis sections were subjected to immunofluorescence staining with $3 \beta$-hydroxysteroid dehydrogenase (HSD3B). Briefly, sections were placed on slides coated with poly-Llysine. After deparaffination with xylene, the sections were washed 3 times with PBS, incubated for 30 minutes with blocking solution (1.5\% normal donkey serum in PBS), and then incubated overnight at $4^{\circ} \mathrm{C}$ with rabbit anti-HSD3B antibody (sc-30820; Santa Cruz Biotechnology) at 1:100 in blocking solution. As a negative control, normal rabbit IgG (ab172730, Abcam) replaced the primary antibody. After washed in PBS, slides were incubated in a 1:200 dilution of donkey polyclonal antibody to rabbit IgG Alexa Fluor (ab175692, Abcam) in blocking solution for 30 minutes. After 4',6-diamidino-2-phenylindole (DAPI; 32670, Sigma-Aldrich) staining, observation and photography were conducted using a microscope system (IX71).

\subsection{In vitro rhGH treatment of Leydig cells from rat testes}

immature Sprague-Dawley rats (PND 21) were killed by $\mathrm{CO}_{2}$ asphyxiation, and the testes were removed. The decapsulated testes were washed with PBS and incubated with collagenase $(0.25 \mathrm{mg} / \mathrm{mL})-\mathrm{RPMI}$ medium (11875093, Gibco, Dublin, Ireland) for $20 \mathrm{~min}$. The interstitial cells from the supernatant were washed 2 times with RPMI medium. To obtain purified Leydig cells, $1 \mathrm{~mL}$ of the interstitial cells was loaded at the top of a 36-60\% (v/v; 2 mL each) Percoll (P1644, Sigma-Aldrich) gradient. After centrifugation at $800 \mathrm{Xg}$ for $25 \mathrm{~min}$, four visible bands of testicular cells were obtained, with highly purified Leydig cells found in the third band from the top, corresponding to a $38-52 \%$ (v/v) Percoll concentration. The Leydig cells were collected, washed twice with RPMI and resuspended in RPMI with 10\% fetal bovine serum (10270106, Gibco) and 1 X Antibiotic-Antimycotic (15240062, Gibco). The purity of the Leydig cells was assessed using HSD3B immunofluorescence staining. Briefly, isolated Leydig cells were plated in $35 \mathrm{~mm}$ culture dishes at $10^{5}$ cells $/ \mathrm{mL}$ and incubated at $37^{\circ} \mathrm{C}$ in a humidified atmosphere of $95 \%$ air and $5 \% \mathrm{CO}_{2}$ for $6 \mathrm{hrs}$. And then, Leydig cells were fixed with $4 \%$ PFA for 5 min and washed 3 times with PBS. After PBS washing, Leydig cells were incubated overnight at $4^{\circ} \mathrm{C}$ with rabbit anti-HSD3B antibody (sc-30820; Santa Cruz Biotechnology) at 1:100 in blocking solution. As a negative control, normal rabbit IgG (ab172730, Abcam) replaced the primary antibody. After washed in PBS, cells were incubated in a 1:200 dilution of donkey polyclonal antibody to rabbit IgG Alexa Fluor (ab150073, Abcam) in blocking solution for 30 minutes. After DAPI (32670, Sigma-Aldrich) staining, observation and photography were conducted using a microscope system (IX71). The HSD3B(+) cells were identified as

Leydig cells. For rhGH treatment, purified Leydig cells were plated in 35-mm culture dishes at $10^{5}$ cells $/ \mathrm{mL}$ and incubated at $37^{\circ} \mathrm{C}$ in a humidified atmosphere of $95 \%$ air and $5 \% \mathrm{CO}_{2}$. After 24 hrs, the medium was removed and replaced with $\operatorname{rhGH}(0,10$, or $50 \mu \mathrm{g} / \mathrm{L})$ and $\mathrm{LH}(10 \mu \mathrm{g} / \mathrm{L})$ in RPMI medium. After $48 \mathrm{hrs}$ of that treatment, the spent media were collected and subjected to enzyme-linked immunosorbent assay (ELISA) (Demeditec Diagnostics) to determine the testosterone concentration. The mRNA expression of the rhGH-treated Leydig cells was analyzed by RT-qPCR.

\subsection{ELISA for circulating testosterone, LH, and IGF1 levels}


On PNDs 24 and 31, samples of rat blood collected via heart puncture were centrifuged at 14,000 rpm for 10 min. The serum supernatants were stored at $-80^{\circ} \mathrm{C}$. Total serum testosterone $(T)$, IGF1, and LH concentrations in male rats were measured on PNDs 24 and 31 by ELISA using testosterone and IGF1 ELISA kits (Demeditec Diagnostics, Kiel-Wellsee, Germany) and LH kit (Shibayagi, Shibukawa, Japan) according to the manufacturers' instructions.

\subsection{Statistical analysis}

Results are expressed as mean \pm standard deviation (SD) values. Statistical calculations were performed using two-tailed Student's t-test (IBM Corporation, Armonk, NY). A p-value of less than 0.05 was considered statistically significant.

\section{Results}

\subsection{Changes in testis weight, seminiferous tubule histology, and mRNA levels of spermatogenic marker genes}

On PND 24, following three daily administrations of rhGH, the testis weights of the $2 \mathrm{IU} / \mathrm{kg}$ rhGH and 1 $\mathrm{IU} / \mathrm{kg}$ rhGH rats were significantly lower than those of the control rats. However, on PND 31, following 10 daily administrations of rhGH, the testis weights of the $2 \mathrm{IU} / \mathrm{kg} \mathrm{rhGH}$ and $1 \mathrm{IU} / \mathrm{kg}$ rhGH rats were significantly higher than those of the control rats. In the testis histology examination, the seminiferous tubule diameter and luminal area were significantly increased in the $2 \mathrm{IU} / \mathrm{kg}$ rhGH rats on PND 31 but not in the $1 \mathrm{lU} / \mathrm{kg}$ rhGH rats. No significant difference in seminiferous tubule diameter or luminal area was observed between the control and 1 or $2 \mathrm{IU} / \mathrm{kg}$ rhGH rats on PND 24 (Fig. 1; Supplemental Fig. 1). The testicular Tnp1, Tnp2, and Prm2 mRNA levels of the rhGH rats were significantly higher than those of the control rats on PND 31 but not on PND 24 (Fig. 2).

\subsection{Changes in the number and size of Leydig cells, testicular steroidogenic pathway gene mRNA levels, and blood testosterone levels}

Quantitative image analysis of HSD17B(+) immunoreactivity in testes revealed a significant increase in the number and size of Leydig cells in rhGH rat testes on PNDs 24 and 31 (Fig. 3; Supplemental Fig. 2). In the HSD3B immunofluorescence labeling of testes from rhGH rats on PND 24, both the number of $\mathrm{HSD} 3 \mathrm{~B}(+)$ Leydig cells and their size was significantly increased compared with the control (Fig. 3; Supplemental Fig. 3). However, the total number of interstitial cells from rhGH rat testes was not different from control on PND 24 or 31. In the RT-qPCR analysis, the mRNA levels of testicular steroidogenic pathway genes, luteinizing hormone/choriogonadotropin receptor (Lhcgr), steroidogenic factor 1 (Sf1), steroidogenic acute regulatory protein (Star), cytochrome P450 family 17 subfamily A member 1 (Cyp17a1), and hydroxysteroid $17 \beta$ dehydrogenase 3 (Hsd17b3), in the rhGH rats were significantly 
higher than those in the control rats on PNDs 24 and 31 (Fig. 4). Serum testosterone levels were significantly higher in the $2 \mathrm{lU} / \mathrm{kg}$ rhGH rats than in the control rats on PNDs 24 and 31 (Fig. 5).

\subsection{Changes in hypothalamic Kiss1 and Gnrh1 and pituitary Lhb mRNA and circulating LH levels}

Hypothalamic Kiss1 and Gnrh1 mRNA levels in the rhGH rats were significantly higher than those in the control rats on PND 24, but they were significantly lower than those in the controls on PND 31. Pituitary $L h b$ mRNA levels in the rhGH rats were significantly lower than those in the control rats on PNDs 24 and 31. No significant differences were found in circulating $\mathrm{LH}$ levels between the rhGH rats and control animals on PND 24 or 31 (Fig. 6).

\subsection{Changes in circulating IGF1 and mRNA levels in the hypothalamus, liver, and testes}

The hypothalamic Igf1 mRNA levels in the rhGH rats were significantly higher than those in the control animals on PND 24, but they were significantly lower on PND 31. The liver Igf1 mRNA levels and blood IGF1 levels of the rhGH rats did not differ significantly from those of the control rats on PND 24 or 31.

The testicular Igf1 mRNA levels of the rhGH rats were significantly higher than those of the control rats on PNDs 24 and 31 (Fig. 7).

\subsection{Changes in Igf1 expression and steroidogenesis in Leydig cells in vitro}

In the immunocytochemical staining, $96.3 \%$ of the isolated interstitial cells were positive for HSD3B. The Igf1, cytochrome P450 family 11 subfamily A member 1 (Cyp11a1), Cyp17a1, cytochrome P450 family 19 subfamily A member 1 (Cyp19a1), and Hsd17b3 mRNA levels in Leydig cells treated with $10 \mu \mathrm{g} / \mathrm{L}$ of rhGH were significantly higher than those in the control cells, but the levels in cells treated with $50 \mu \mathrm{g} / \mathrm{L}$ of rhGH did not differ from the control cells. Compared with the control, Sf1 mRNA levels were significantly higher in Leydig cells treated with 10 or $50 \mu \mathrm{g} / \mathrm{L}$ of rhGH. hydroxy-delta-5-steroid dehydrogenase, 3 betaand steroid delta-isomerase 1 (Hsd3b1) mRNA levels, on the other hand, were significantly higher in Leydig cells treated with $10 \mu \mathrm{g} / \mathrm{L}$ of rhGH but lower in cells treated with $50 \mu \mathrm{g} / \mathrm{L}$ of rhGH, compared with the control. Lhcgr and Star mRNA levels did not differ significantly between the rhGH-treated cells and the control. In the spent media, testosterone levels were significantly higher than the control in Leydig cells treated with $10 \mu \mathrm{g} / \mathrm{L}$ of rhGH but not in those treated with $50 \mu \mathrm{g} / \mathrm{L}$ of rhGH (Fig. 8).

\section{Discussion}

\subsection{Effect of rhGH on spermatogenesis and steroidogenesis in immature rats}


Correlations between $\mathrm{GH}$ and sexual maturation have been reported in both sexes (Zaczek et al., 2002; Sanchez-Cardenas et al., 2010). In immature male rats, puberty was significantly advanced, together with an increase in total body weight and reproductive organ weight, following rhGH administration (Ronis et al., 1998). In this study, the testis weights of the $2 \mathrm{IU} / \mathrm{kg}$ rhGH rats were significantly lower than those of the control rats on PND 24, although that difference was mitigated on PND 31. Similarly, in immature male dogs, a high dose of $\mathrm{rGH}(25 \mathrm{lU} / \mathrm{kg} /$ day) induced atrophy of the testes and accessory organs (Sjögren et al., 1998). GH can induce apoptosis and atretic changes in the ovaries and testes of mammals, including humans, by activating the PI3K-Akt pathway (Santos et al., 1999; Sirotkin, 2005). Though no explanation for the reduced testis weights in rhGH rats during the early prepubertal period has been confirmed, high doses of rhGH in the early prepubertal period might transiently reduce testis development in a way that is impermanent and recoverable. In histology, the diameter and luminal areas of the seminiferous tubules were visibly increased in the $2 \mathrm{IU} / \mathrm{kg} \mathrm{rhGH}$ rats on PND 31. In parallel, testicular mRNA levels of spermatogenic marker genes in the rhGH rats were significantly higher than those in the control rats on PND 31, indicating that rhGH activated spermatogenesis in the immature rats. Similarly, in immature rats, $\mathrm{GH}$ treatment for four weeks induced testicular growth and germ cell differentiation (Ipsa et al., 2019). In the $2 \mathrm{IU} / \mathrm{kg}$ rhGH rats, blood testosterone levels were significantly higher than in the control rats on PNDs 24 and 31. Similarly, rhGH injection stimulated testosterone synthesis in both immature and adult rodents (Colón et al., 2005; Sriraman et al., 2005). Given that circulating LH levels did not differ significantly between the control and rhGH rats, the activation of androgen production might indicate that rhGH has a direct effect on Leydig cells. In Leydig cell cultures, rhGH directly activated steroidogenesis (Wang \& Hardy, 2004; Ipsa et al., 2019). In rat testes, HSD3B(+) progenitor Leydig cells are typically observed on PND 21 before they increase in number and become HSD17B(+) immature Leydig cells that go on to differentiate into functional adult Leydig cells (Hu et al., 2010). In light of the observed mRNA levels of steroidogenic pathway genes, increases in the number and mean size of $\mathrm{HSD17B}(+)$ Leydig cells in rhGH rat testes on PNDs 24 and 31, and the increased number and mean size of $\mathrm{HSD} 3 \mathrm{~B}(+)$ Leydig cells in rhGH rat testes on PND 24, prepubertal rhGH administration might have accelerated the functional differentiation of progenitor Leydig cells (PLCs) into immature, testosterone-producing Leydig cells. In the testes, GH and IGF1 modulate the proliferation and steroidogenesis of Leydig cells via the MAPK-ERK, JAK-STAT, and PI3K-AKT pathways (Rotwein, 2012; Ipsa et al., 2019). In the HSD3B(+) progenitor Leydig cells isolated on PND 21, $10 \mu \mathrm{g} / \mathrm{L}$ of rhGH treatment increased the expression of steroidogenic pathway gene mRNA (Igf1, Sf1, Cyp11a1, Cyp17a1, Cyp19a1, $H s d 3 b 1$, and $H s d 17 b 3)$ and testosterone secretion. This suggests that rhGH-treatment directly activates steroidogenesis in progenitor Leydig cells, which is consistent with the results of previous studies (Dufau, 1988; Maran et al., 2000). The increase in circulating testosterone found in rhGH rats on PNDs 24 and 31 might be attributable to greater steroidogenic differentiation of PLCs to testosterone-producing Leydig cells, activating the spermatogenesis.

\section{2. rhGH triggered changes in kisspeptin, $\mathrm{GnRH}$, and $\mathrm{LH}$ in immature male rats}


During the prepubertal period, kisspeptin activates the HPG axis and increases sex steroids (Soliman et al., 2014; Devesa \& Caicedo, 2019). In male rats, hypothalamic kisspeptin and GnRH concentrations were elevated after PND 7 (Semaan et al., 2013; Luo et al., 2016). In this study, hypothalamic Kiss1 and Gnrh1 mRNA levels in the rhGH rats were significantly higher than those in the control rats on PND 24, when kisspeptin is elevated in male rats. Thus, prepubertal rhGH administration might potentiate hypothalamic kisspeptin and GnRH production. In adult rodents, hypothalamic Kiss 1 and Gnrh1 mRNA are downregulated by sex steroids (Smith, 2008; $\mathrm{Ng}$ et al., 2009). In this study, circulating testosterone levels in the rhGH rats were significantly higher than those in the control rats on PNDs 24 and 31 . Although the circulating LH levels of the rhGH rats did not differ from those of the control rats on PND 24 or 31, the pituitary $L h b$ mRNA levels in the rhGH rats were significantly lower than those in the control rats on PNDs 24 and 31 , suggesting that elevated testosterone levels provide negative feedback for the expression of pituitary $L h b$.

\section{3. rhGH triggered IGF1 changes in the hypothalamus, liver, and testes of immature rats}

IGF1 mediates GH-dependent and GH-independent anabolism and growth (Cheng \& Chen, 1995; Kolodziejczyk et al., 2003). In rodents and primates, hypothalamic IGF1 expression increases at puberty, which activates kisspeptin-GnRH neurons (Hiney et al., 1996; Wolfe et al., 2014; Huh et al., 2021). In human and mouse brains, hypothalamic GnRH neurons express the IGF1 receptor (D'Ercole et al., 1996; Divall et al., 2010). In prepubertal female rats, an intracerebroventricular infusion of IGF1 stimulated the secretion of GnRH and might advance the onset of puberty (Hiney et al., 1991 and 1996). In prepubertal male rats, a central infusion of IGF1 antiserum delayed pubertal development (Pazos et al., 1999). Altogether, brain IGF1 is an important factor in the initiation of puberty. In this study, hypothalamic Igf1 mRNA was increased in the rhGH rats on PND 24, suggesting that the activation of kisspeptin-GnRH expression can be attributed to the activation of hypothalamic IGF1. In addition, in the hypothalamus, sex steroids activate the GH-IGF1 axis, accelerating the growth and maturation of reproductive organs for puberty (Veldhuis, 1997). Together, increased hypothalamic Igf1 mRNA in the rhGH rats on PND 24 might be attributable to the elevated testosterone levels, as well as the direct action of rhGH on hypothalamic Igf1 expression. In contrast, on PND 31, hypothalamic Igf1 mRNA levels in the rhGH rats were significantly lower than those in the control rats, which could be a result of negative feedback from elevated androgens at puberty in the rhGH rats. Stimulation of IGF1 production in the liver has been considered to be a major effect of GH (LeRoith \& Roberts Jr, 2003; Bielohuby et al., 2009). Systemic IGF1 plays a major modulatory role in testicular endocrine function. In the rhGH rats in this study, however, liver Igf1 mRNA and blood IGF1 levels tended to increase, though not to a statistically significant degree, by PNDs 24 and 31. Similarly, in immature mice given rhGH, circulating IGF1 and hepatic cell Igf1 mRNA levels did not increase (Mireuta et al., 2014). Of note, in the rhGH rats in this study, testicular Igf1 mRNA levels were significantly higher than those in the control rats on both PND 24 and 31. Similarly, in immature hypophysectomized rats, rhGH increased testicular IGF1 levels (Grizard, 1994; Laron \& Klinger, 1998; Diez-Caballero et al., 2006). Given that IGF1 and cognate receptor are expressed in germ cells, Leydig cells and Sertoli cells (Grizard, 1994; Wang \& Hardy, 2004; Diez-Caballero et al., 2006; Griffeth et 
al., 2014), intratesticular IGF1 could regulate various aspects of testicular function in both autocrine and paracrine manners. In rodents, IGF1 can promote the proliferation, maturation, and steroidogenesis of Leydig cells by means of para- and autocrine action (Khan et al., 1992; LeRoith \& Roberts Jr, 2003; DiezCaballero et al., 2006). In mouse Leydig cells, the expression of the LH receptor and response to LH are potentiated by IGF1 (Lin et al., 1986; Kasson \& Hsueh, 1987). In the rhGH rat testes in this study, the number and size of $\mathrm{HSD} 3 \mathrm{~B}(+)$ and $\mathrm{HSD} 17 \mathrm{~B}(+)$ Leydig cells increased significantly. In addition, in the $\mathrm{HSD} 3 \mathrm{~B}(+)$ progenitor Leydig cells isolated on PND 21, rhGH treatment increased the expression of Igf1 mRNA. Therefore, testicular increases in IGF1 could mediate functional differentiation of testosteroneproducing Leydig cells in rhGH rats, and the increased circulating testosterone in rhGH rats may be due to the increased LH response in Leydig cells by the testicular IGF1. In the rhGH rats in this study, the elevated testicular IGF1 levels might be responsible for the activation of testosterone production and spermatogenesis (Fig. 9). In gonadotropin-independent precocious puberty (GIPP), sexual maturation is induced by sex steroids that increase through a gonadotropin-independent mechanism such as testotoxicosis, tumors, or environmental hormones (Kremer et al., 1993; Traggiai and Stanhope, 2003). The elevation of testicular IGF1 through prepubertal administration of rhGH could thus evoke the early onset of sexual maturation without increasing circulating LH levels, resembling GIPP.

\section{Conclusion}

In prepubertal male rats, rhGH administration increased testicular but not systemic IGF1 levels, which potentiated testosterone production in Leydig cells and spermatogenesis.

\section{Abbreviations}

$\%(\mathrm{v} / \mathrm{v})$ percent (volume per volume)

${ }^{\circ} \mathrm{C}$ degree Celsius

$\mu \mathrm{m}$ micrometer

a.m. ante meridiem

$\mathrm{CO}_{2}$ carbon dioxide

Cyp17a1 cytochrome P450 family 17 subfamily A member 1

ELISA enzyme-linked immunosorbent assay

GH growth hormone

GIPP gonadotropin-independent precocious puberty

GnRH gonadotropin-releasing hormone 
Gnrh1 gonadotropin Releasing Hormone 1

HPG axis hypothalamus-pituitary-gonad axis

hr hour

HSD17b 17ß-hydroxysteroid dehydrogenase

Hsd17b3 hydroxysteroid $17 \beta$ dehydrogenase 3

Hsd3b 3ß-hydroxysteroid dehydrogenase

Hsd3b1 hydroxy-delta-5-steroid dehydrogenase, 3 beta- and steroid delta-isomerase 1

Igf1 insulin-like growth factor-1

IgG immunoglobulin G

IU international units

kg kilogram

Kiss1 KiSS-1 Metastasis Suppressor

L liter

LH luteinizing hormone

Lhb luteinizing hormone beta polypeptide

Lhcgr luteinizing hormone/choriogonadotropin receptor

$\mathrm{mL}$ milliliter

mRNA messenger RNA

PBS phosphate buffered saline

PCR polymerase chain reaction

PFA paraformaldehyde

PLC progenitor Leydig cell

PND postnatal day

Prm protamine 
rhGH recombinant human growth hormone

RNA ribonucleic acid

Rpl7 ribosomal protein $L 7$

rpm revolutions per minute

RPMI Roswell Park Memorial Institute medium

RT-qPCR real-time reverse transcription-polymerase chain reaction

SD standard deviation

Sf1 Steroidogenic factor 1

Star steroidogenic acute regulatory protein

T testosterone

Tnp1 transition protein 1

Tnp2 transition protein 2

$\mu g$ microgram

\section{Declarations}

\section{Availability of data and materials}

The datasets used and/or analysed during the current study are available from the corresponding author on reasonable request.

\section{Ethics declarations}

This study was approved by the Hanyang University Institutional Animal Care and Use Committee (HYIACUC-11-021).

\section{Consent for publication}

Not applicable.

\section{Competing interests}


The authors declare that they have no competing interests.

\section{Funding}

This research did not receive any specific grant from any funding agency in the public, commercial, or not-for-profit sector.

\section{Contributions}

$\mathrm{YX}$ and $\mathrm{CYH}$ contributed to the experiment performance. $\mathrm{YX}$ contributed to the manuscript writing and submission. MCG, MJP, YX, and CYH contributed to the experiment performance and manuscript revision. All have read this final version and have approved this submission.

\section{Corresponding author}

Correspondence to Mi Jung Park.

\section{Acknowledgements}

Not applicable.

\section{Author information}

Affiliations

Department of Pediatrics, Sanggye Paik Hospital, Inje University College of Medicine, Seoul, Korea.

Yang Xu, Chang Yong Han, and Myung Chan Gye

Myung Chan Gye, Ph.D. Department of Life Science, Hanyang University, Seoul, Korea.

Mi Jung Park

\section{References}

1. Bielohuby M, Sawitzky M, Johnsen I, Wittenburg D, Beuschlein F, Wolf E, \& Hoeflich. A 2009 Decreased p44/42 mitogen-activated protein kinase phosphorylation in gender- or hormone-related but not during age-related adrenal gland growth in mice. Endocrinology 150 1269-1277.

2. Blum WF, Crowe BJ, Quigley CA, Jung H, Cao D, Ross JL, Braun L, Rappold G. \& SHOX Study Group 2007 Growth hormone is effective in treatment of short stature associated with short stature 
homeobox-containing gene deficiency: two-year results of a randomized, controlled, multicentertrial. Journal of Clinical Endocrinology and Metabolism 92 219-228.

3. Cannarella R, Condorelli RA, La Vignera S, Calogero AE. Effects of the insulin-like growth factor system on testicular differentiation and function: a review of the literature. Andrology. 2018;6:3-9.

4. Chandrashekar V, Bartke A, Awoniyi CA, Tsai-Morris CH, Dufau ML, Russell LD. \& Kopchick JJ 2001 Testicular endocrine function in GH receptor gene disrupted mice. Endocrinology 142 3443-3450.

5. Chang HP, Yang SF, Wang SL, Su PH. Associations among IGF-1, IGF2, IGF-1R, IGF-2R, IGFBP-3, insulin genetic polymorphisms and central precocious puberty in girls. BMC Endocrine Disorders. 2018;18:66.

6. Cheng CM, Chen TT. Synergism of GH and IGF-I in stimulation of sulphate uptake by teleostean branchial cartilage in vitro. J Endocrinol. 1995;147:67-73.

7. Christoforidis A, Maniadaki I, Stanhope R. Growth hormone / insulin-like growth factor-1 axis during puberty. Pediatric Endocrinology Reviews. 2005;3:5-10.

8. Colón E, Svechnikov KV, Carlsson-Skwirut C, Bang P, Soder O. Stimulation of steroidogenesis in immature rat Leydig cells evoked by interleukin-1alpha is potentiated by growth hormone and insulinlike growth factors. Endocrinology. 2005;146:221-30.

9. Crowe BJ, Rekers-Mombarg LTM, Robling K, Wolka AM Jr, Wit GBC. JM \& European Idiopathic Short Stature Group. 2006 Effect of growth hormone dose on bone maturation and puberty in children with idiopathic short stature. The Journal of Clinical Endocrinology Metabolism 91 169-75.

10. D'Ercole AJ, Ye P, Calikoglu AS, Gutierrez-Ospina G. The role of the insulin-like growth factors in the central nervous system. Mol Neurobiol. 1996;13:227-55.

11. Darendelier F, Hindmarsh PC, Preece MA, Cox L. \& Brook CGD $1990 \mathrm{GH}$ increases the rate of sexual maturation. Acta Endocrinology 122 414-416.

12. Devesa J, Caicedo $D$. The role of growth hormone on ovarian functioning and ovarian angiogenesis. Frontiers in Endocrinology (Lausanne). 2019;10:450.

13. Diez-Caballero F, Castilla-Cortázar I, Garcia-Fernandez M, Puche JE, Diaz-Sanchez M, Casares AD, Aliaga-Montilla MA, Rodriguez-Borrajo C. \& Barón SG 2006 Little effects of Insulin-like Growth FactorI on testicular atrophy induced by hypoxia. BMC Urology 64.

14. Divall SA, Williams TR, Carver SE, Koch L, Bruning JC, Kahn CR, Wondisford F, Radovick S. \& Wolfe A 2010 Divergent roles of growth factors in the GnRH regulation of puberty in mice. Journal of Clinical Investigation 120 2900-2909.

15. Dufau ML. Endocrine regulation and communicating functions of the Leydig cell. Annu Rev Physiol. 1988;50:483-508.

16. Griffeth RJ, Bianda V, Nef S. The emerging role of insulin-like growth factors in testis development and function. Basic Clinical Andrology. 2014;24:12.

17. Grizard G. IGF(s) and testicular function. Secretion and action of IGF-I on Leydig cells. Contracept Fertil Sex. 1994;22:551-5. 
18. Hiney JK, Ojeda SR. \& Dees WL 1991 Insulin-like growth factor I: a possible metabolic signal involved in the regulation of female puberty. Neuroendocrinology 54 420-423.

19. Hiney JK, Srivastava V, Nyberg CL, Ojeda SR. \& Dees WL 1996 Insulin-like growth factor I of peripheral origin acts centrally to accelerate the initiation of female puberty. Endocrinology 137 3717-3728.

20. Hu G, Lin H, Chen G, Chen G, Chen B, Lian Q, Hardy DO, Zirkin BR. \& Ge R 2010 Deletion of the IGF-1 gene: suppressive effects on adult Leydig cell development. Journal of Andrology 31 379-387.

21. Huh K, Nah WH, Xu Y, Park MJ, Gye MC. Effects of recombinant human growth hormone on the onset of puberty, Leydig cell differentiation, spermatogenesis and hypothalamic KISS1 expression in immature male rats. The World Journal of Men's Health. 2021;39:381-8.

22. Ipsa E, Cruzat VF, Kagize JN, Yovich JL. \& Keane KN 2019 Growth hormone and insulin-like growth factor action in reproductive tissues. Frontiers in Endocrinology (Lausanne) 10777.

23. Kamp GA, Waelkens JJJ, de Muinck Keizer-Schrama SMPF, Delemarre-Van de Waal HA, VerhoevenWind L, Zwinderman AH, Wit. JM 2002 High dose growth hormone treatment induces acceleration of skeletal maturation and an earlier onset of puberty in children with idiopathic short stature. Archives of Disease in Childhood 87 215-220.

24. Kanzaki M. \& Morris PL 1999 Growth hormone regulates steroidogenic acute regulatory protein expression and steroidogenesis in Leydig cell progenitors. Endocrinology 140 1681-1686.

25. Kasson BG, Hsueh AJW. Insulin-like growth factor-I augments gonadotropin-stimulated androgen biosynthesis by cultured rat testicular cells. Mol Cell Endocrinol. 1987;52:27-34.

26. Keene DE, Suescun MO, Bostwick MG, Chandrashekar V, Bartke A. \& Kopchick JJ 2002 Puberty is delayed in male growth hormone receptor gene-disrupted Mice. Journal of Andrology 23 661-668.

27. Khan S, Teerds K, \& Dorrington J. Growth factor requirements for DNA synthesis by Leydig cells from the immature rat. Biol Reprod. 1992;46:335-41.

28. Kolodziejczyk J, Gertler A, Leibovich H, Rzasa J, Gregoraszczuk EL. Synergistic action of growth hormone and insulin-like growth factor I (IGF-I) on proliferation and estradiol secretion in porcine granulosa and theca cells cultured alone or in coculture. Theriogenology. 2003;60:559-70.

29. Kremer H, Mariman E, Otten BJ, Moll GW Jr, Stoelinga GB, Wit JM, Jansen M, Drop SL, Faas B, Ropers $\mathrm{HH}$, et al. 1993 Cosegregation of missense mutations of the luteinizing hormone receptor gene with familial male-limited precocious puberty. Human Molecular Genetics 2 1779-1783.

30. Laron Z, Klinger B. Effect of insulin-like growth factor-I treatment on serum androgens and testicular and penile size in males with Laron syndrome (primary growth hormone resistance). Eur $\mathrm{J}$ Endocrinol. 1998;138:176-80.

31. LeRoith D, Roberts Jr. CT 2003 The insulin-like growth factor system and cancer. Cancer Letters 195 $127-137$.

32. Lin T, Haskell J, Vinson N, Terracio L. Direct stimulatory effects of insulin-like growth factor I on Leydig cell steroidogenesis in primary culture. Biochem Biophys Res Commun. 1986;137:950-6. 
33. Livak KJ, Schmittgen TD. Analysis of relative gene expression data using real-time quantitative PCR and the $2^{-\Delta \Delta C T}$ method. Methods. 2001;25:402-8.

34. Luo Q, Hou Y, Yin N, Zhang H. Expression of kisspeptin/kiss1r system in developing hypothalamus of female rat and the possible effects on reproduction development and maintenance. Journal of the Chinese Medical Association. 2016;79:546-53.

35. Maran RRM, Sivakumar R, Ravisankar B, Valli G, Ravichandran K, Arunakaran J. \& Aruldhas MM 2000 Growth hormone directly stimulates testosterone and oestradiol secretion by rat Leydig cells in vitro and modulates the effects of LH and T3. Endocrine Journal 47 111-118.

36. Mireuta M, Birman E, Barmash M, Pollak M. Quantification of binding of IGF-1 to BI 836845, a candidate therapeutic antibody against IGF-1 and IGF-2, and effects of this antibody on IGF-1: IGFBP3 complexes in vitro and in male C57BL/ 6 mice. Endocrinology. 2014;155:703-15.

37. Navarro VM, Fernandez-Fernandez R, Castellano JM, Roa J, Mayen A, Barreiro ML, Gaytan F, Aguilar E, Pinilla L, Dieguez C, et al. 2004 Advanced vaginal opening and precocious activation of the reproductive axis by KISS1 peptide, the endogenous ligand of GRP54. The Journal of Physiology 561 379-386.

38. Ng Y, Wolfe A, Novaira HJ, Radovick S. Estrogen regulation of gene expression in GnRH neurons. Mol Cell Endocrinol. 2009;303:25-33.

39. Pazos F, Sánchez-Franco F, Balsa J, López-Fernandez J, Escalada J, \& Cacicedo L. Regulation of gonadal and somatotropic axis by chronic intraventricular infusion of insulin-like growth factor 1 antibody at the initiation of puberty in male rat. Neuroendocrinology. 1999;69:408-16.

40. Roith DL, Bondy C, Yakar S, Liu JL. \& Butler A 2001 The somatomedin hypothesis. Endocrine reviews 22 53-74.

41. Romano AA, Dana K, Bakker B, Davis DA, Hunold JJ, Jacobs J, Lippe B. Growth response, near-adult height, and patterns of growth and puberty in patients with Noonan syndrome treated with growth hormone. The Journal of Clinical Endocrinology Metabolism. 2009;94:2338-44.

42. Ronis MJ, Badger TM, Shema SJ, Roberson PK, Shaikh F. Effects on pubertal growth and reproduction in rats exposed to lead perinatally or continuously throughout development. Journal of Toxicology Environmental Health Part A. 1998;53:327-41.

43. Rosen CJ. Serum insulin-like growth factors and insulin-like growth factor-binding proteins: clinical implications. Clin Chem. 1999;45:1384-90.

44. Rotwein P. Mapping the growth hormone-Stat5b-IGF-I transcriptional circuit. Trends in Endocrinology Metabolism. 2012;23:186-93.

45. Sanchez-Cardenas C, Fontanaud P, He Z, Lafont C, Meunier A, Schaeffer M, Carmignac D, Molino F, Country N, Bonnefont $X$, et al. 2010 Pituitary growth hormone network responses are sexually dimorphic and regulated by gonadal steroids in adulthood. roceedings of the National Academy of Sciences of the United States of America 107 21878-21883.

46. Santos RL, Silva CM, Ribeiro AF, Vasconcelos AC, Pesquero JL, Coelho SJ, Serakides R. \& Reis SR 1999 Effect of growth hormone and induced IGF-1 release on germ cell population and apoptosis in 
the bovine testis. Theriogenology 51 975-984.

47. Semaan SJ, Tolson KP, Kauffman AS. The development of kisspeptin circuits in the mammalian brain. Adv Exp Med Biol. 2013;784:221-52.

48. Sirotkin AV. Control of reproductive processes by growth hormone: extra- and intracellular mechanisms. Vet J. 2005;170:307-17.

49. Sjögren I, Jönsson M, Madej A, Johansson HE, Plöen. L 1998 Effects of very high doses of human growth hormone (hGH) on the male reproductive system in the dog. Andrologia 30 37-42.

50. Skorupskaite K, George JT, Anderson RA. The kisspeptin-GnRH pathway in human reproductive health and disease. Human Reproduction Update. 2014;20:485-500.

51. Smith JT. Kisspeptin signaling in the brain: Steroid regulation in the rodent and ewe. Brain Res Rev. 2008;57:288-98.

52. Soliman A, Sanctis VD, Elalaily R, Bedair S. 2014 Advances in pubertal growth and factors influencing it: Can we increase pubertal growth? Indian Journal of Endocrinology and Metabolism 18 S53-62.

53. Sriraman V, Anbalagan M, \& Rao AJ. Hormonal regulation of Leydig cell proliferation and differentiation in rodent testis: a dynamic interplay between gonadotrophins and testicular factors. Reproductive BioMedicine Online. 2005;11:507-18.

54. Stanhope R, Albanese A, Hindmarsh P, Brook. CDG 1992 The effects of GH therapy on spontaneous sexual development. Hormone Research 38 9-13.

55. Tena-Sempere M. KISS1 and reproduction: focus on its role in the metabolic regulation of fertility. Neuroendocrinology. 2006;83:275-81.

56. Traggiai C, Stanhope R. Disorders of pubertal development. Best Practice Research Clinical Obstetrics Gynaecology. 2003;17:41-56.

57. Veldhuis JD, Metzger DL, Martha PM Jr, Mauras N, Kerrigan JR, Keenan B, Rogol AD, Pincus SM. Estrogen and testosterone, but not a nonaromatizable androgen, direct network integration of the hypothalamo-somatotrope (growth hormone)-insulin-like growth factor I axis in the human: evidence from pubertal pathophysiology and sex-steroid hormone replacement. The Journal of Clinical Endocrinology Metabolism. 1997;82:3414-20.

58. Wang G, Hardy PM. Development of Leydig cells in the insulin-like growth factor-I (IGF-1) knockout mouse: Effects of IGF-1 replacement and gonadotropic stimulation. Biol Reprod. 2004;70:632-9.

59. Wolfe A, Divall S, Wu S. The regulation of reproductive neuroendocrine function by insulin and insulin-like growth factor-1 (IGF-1). Front Neuroendocrinol. 2014;35:558-72.

60. Zaczek D, Hammond J, Suen L, Wandji S, Service D, Bartke A, Chandrashekar V, Coschigano K, Kopchick J. Impact of growth hormone resistance on female reproductive function: new insights from growth hormone receptor knockout mice. Biol Reprod. 2002;67:1115-24.

\section{Figures}



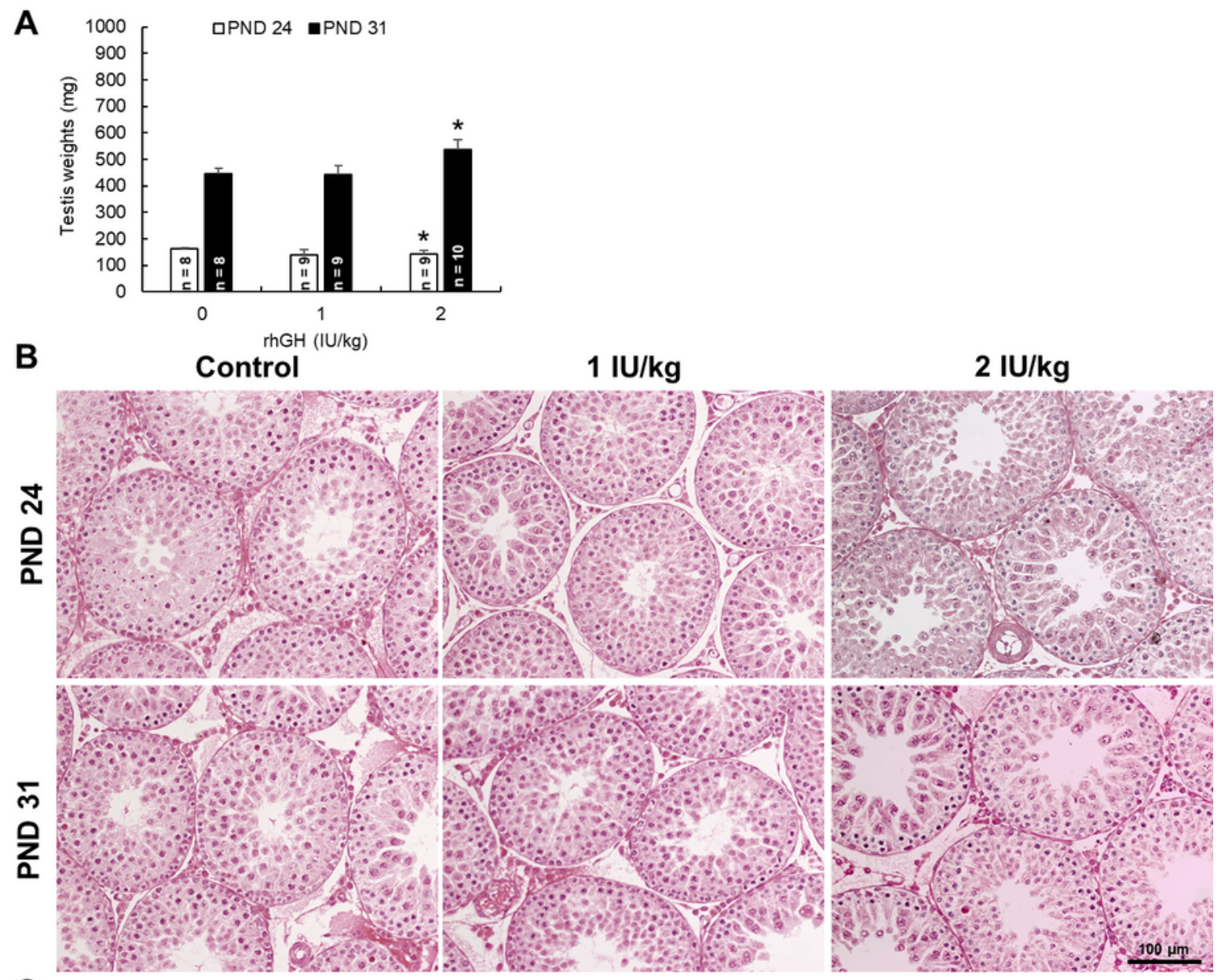

C
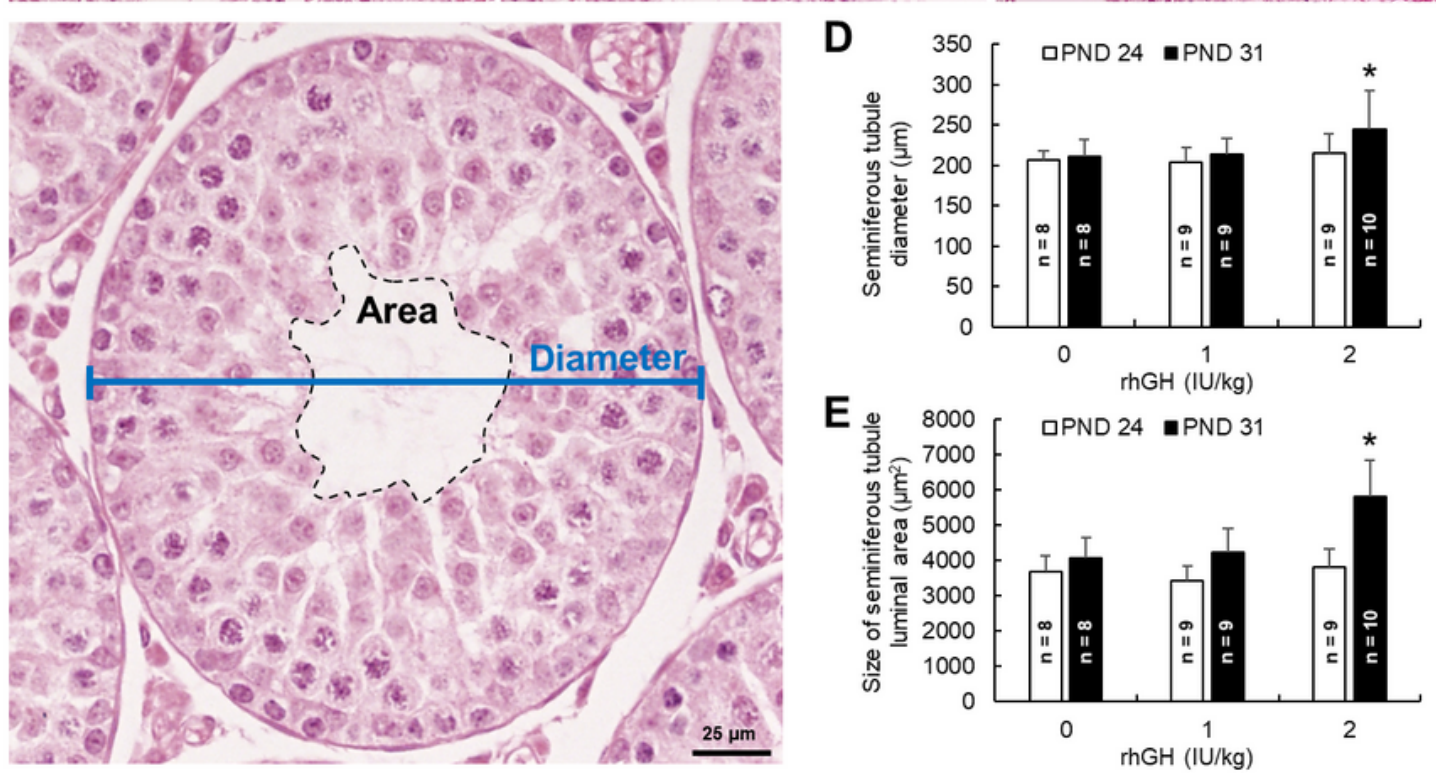

\section{Figure 1}

The effects of rhGH on testis weight, histology, seminiferous tubule diameter, and size of the luminal area in immature rats. (A) The testis weights in immature rats given rhGH. (B) Hematoxylin and eosin staining of testes from immature rats. (C) Image analysis of seminiferous tubule diameter (blue line) and luminal area (dotted line). (D) Diameter of seminiferous tubules from immature rats. (E) Size of the luminal area 
of seminiferous tubules from immature rats. Values presented are the mean \pm SD. ${ }^{*}$, significantly different from control rats by Student t-test at $\mathrm{p} \otimes 0.05$.
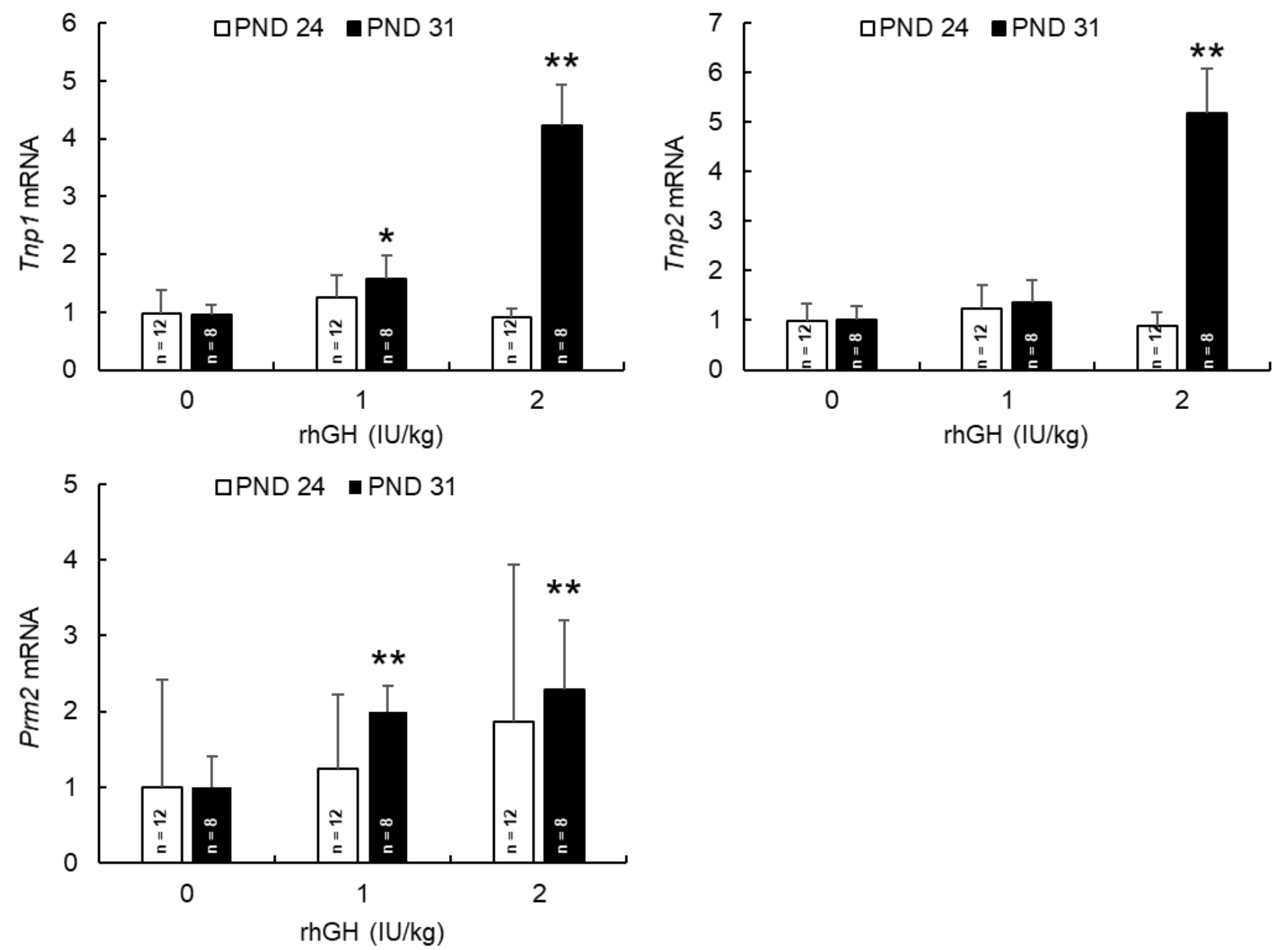

Figure 2

The effect of rhGH on spermatogenic marker mRNA in immature rats. Testicular Tnp1, Tnp2, and Prm2 mRNA levels were examined using RT-qPCR. Values are presented as the mean \pm SD. * and **, significantly different from control rats by Student t-test at $p \otimes 0.05$ and 0.01 , respectively. 

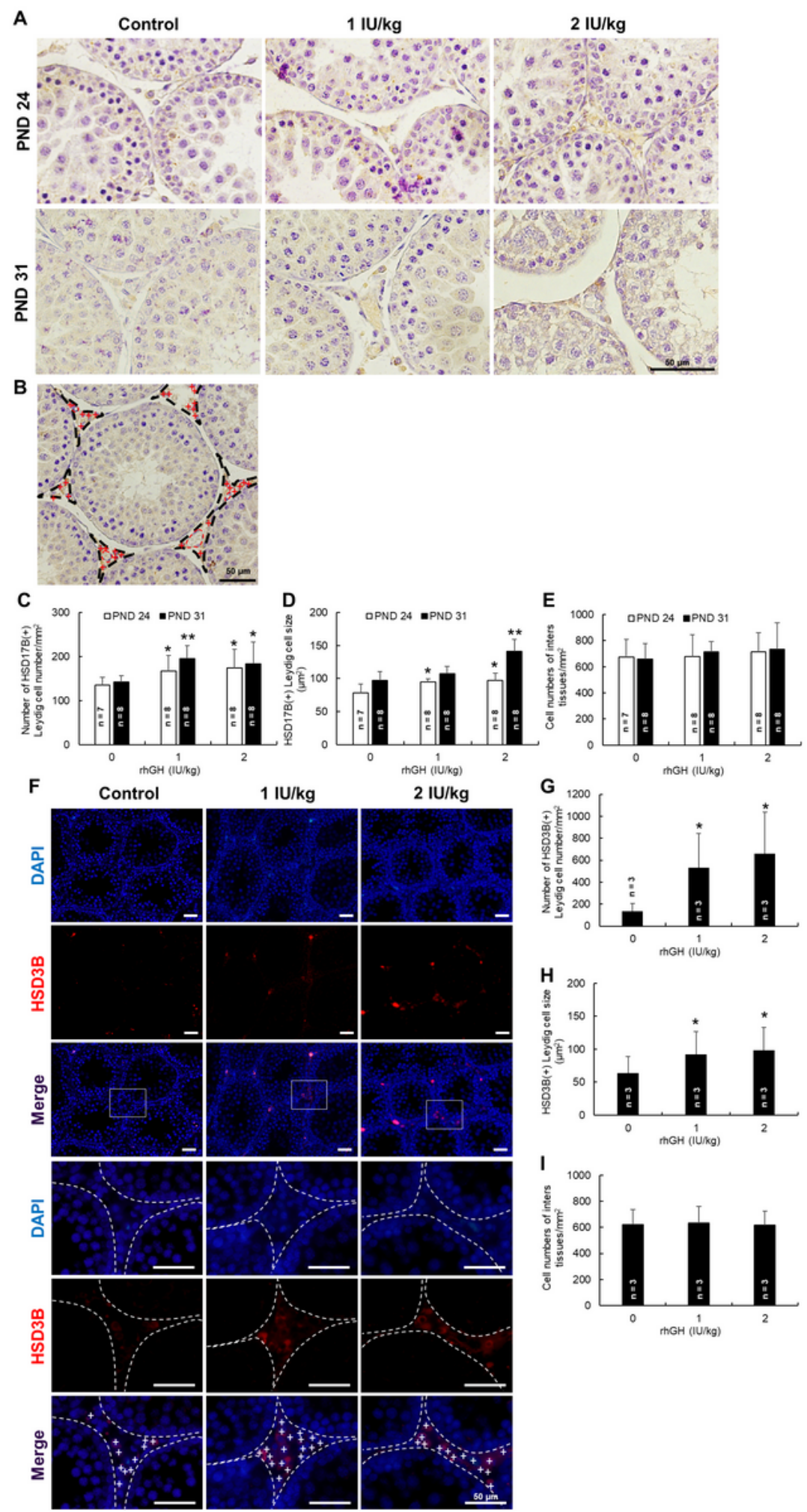

Figure 3

The effects of rhGH on HSD3B(+) and HSD17B(+) Leydig cells in immature rat testes. (A) Immunohistochemistry of HSD17B in immature rat testes on PNDs 24 and 31. (B) Image analysis of HSD17B(+) Leydig cells. Red cross, nuclei of Leydig cells; black dotted line, boundary of HSD17B(+) Leydig cells; red dotted line, boundary of blood vessels. (C) Number of HSD17B(+) Leydig cells in each unit area (1 mm2) of the testes. (D) Mean size of HSD17B(+) Leydig cells. (E) Total number of 
HSD17B(+) interstitial cells in the testes of immature rats on PNDs 24 and 31. Values are presented as the mean $\pm S D$. * and $*$, significantly different from control rats by Student t-test at $\mathrm{p} \otimes 0.05$ and 0.01 , respectively. (F) Immunofluorescence of HSD3B in immature rat testes on PND 24. White cross, nuclei of Leydig cells; white dotted line, boundary of $\operatorname{HSD3B}(+)$ Leydig cells; white box, area shown in the high magnification photograph. (G) Number of HSD3B(+) Leydig cells in each unit area $(1 \mathrm{~mm} 2)$ of the testes. $(\mathrm{H})$ Mean size of $\mathrm{HSD3B}(+)$ Leydig cells. (I) Total number of $\operatorname{HSD3B}(+)$ interstitial cells in the testes of immature rats on PND 24. Values are presented as the mean \pm SD. * and $* *$, significantly different from control rats by Student t-test at $\mathrm{p} \otimes 0.05$ and 0.01 , respectively.

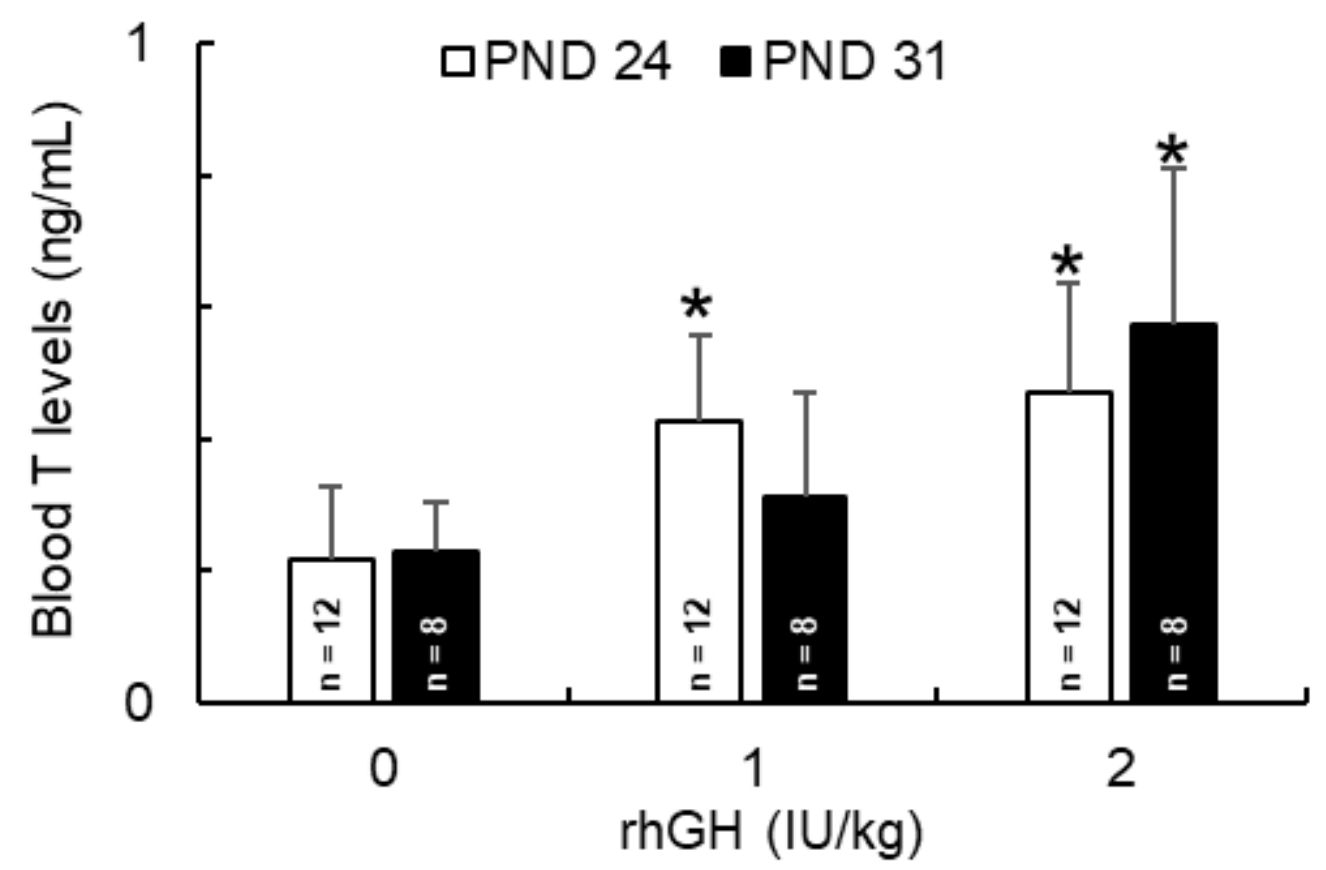

Figure 4

Effects of rhGH on blood testosterone levels in immature male rats. ELISA for blood testosterone levels on PNDs 24 and 31 . Values are presented as the mean \pm SD. *, significantly different from control rats by Student t-test at $\mathrm{p} \otimes 0.05$. 

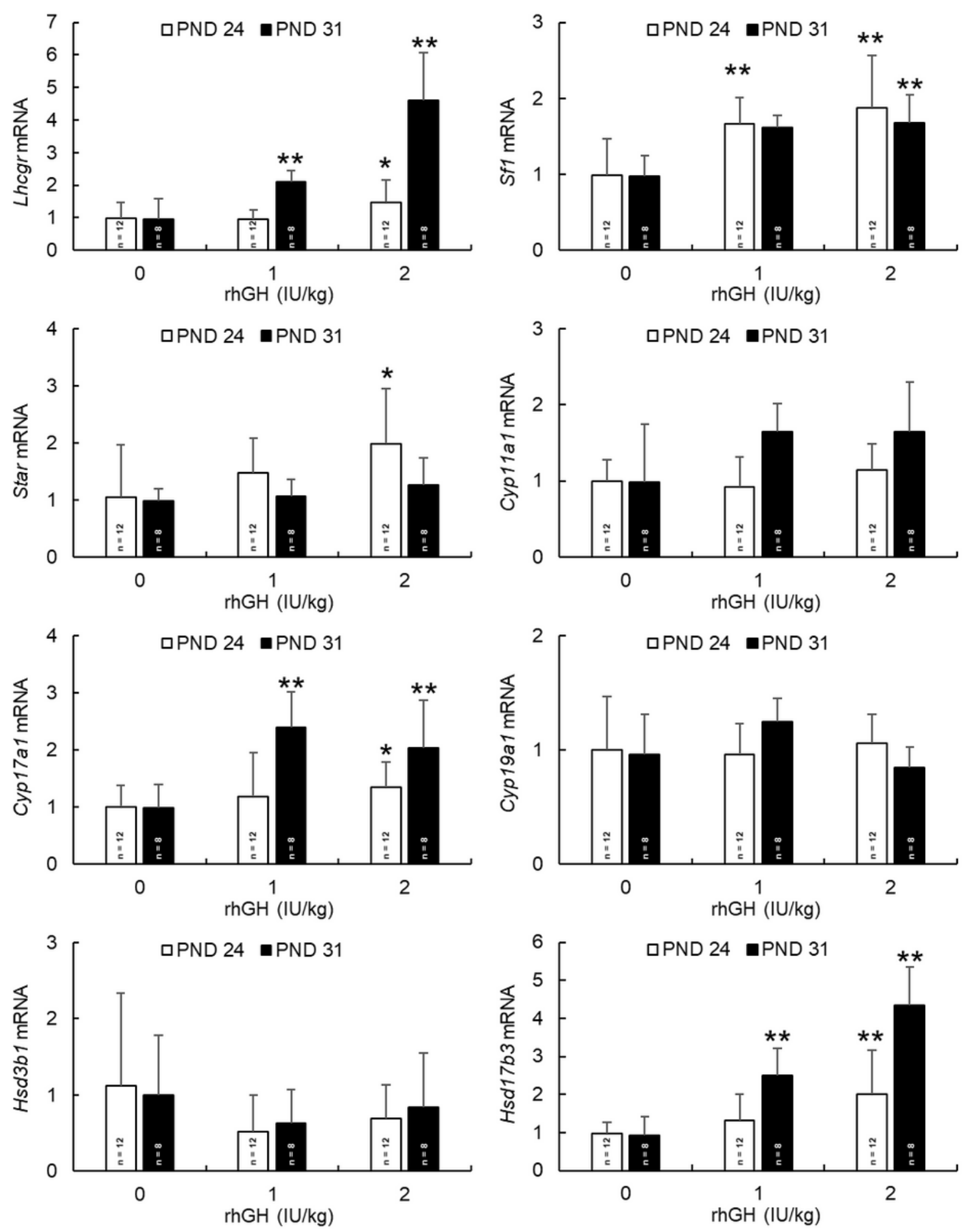

Figure 5

Effects of rhGH on the expression of steroidogenic pathway gene mRNA in immature male rats. RT-qPCR analysis of Lhcgr, Sf1, Star, Cyp17a1, Hsd3b1, and Hsd17b3 mRNA levels in the testes on PNDs 24 and 31 . Values are presented as the mean $\pm \mathrm{SD}$. * and $* *$, significantly different from control rats by Student ttest at $\mathrm{p} \otimes 0.05$ and 0.01 , respectively. 

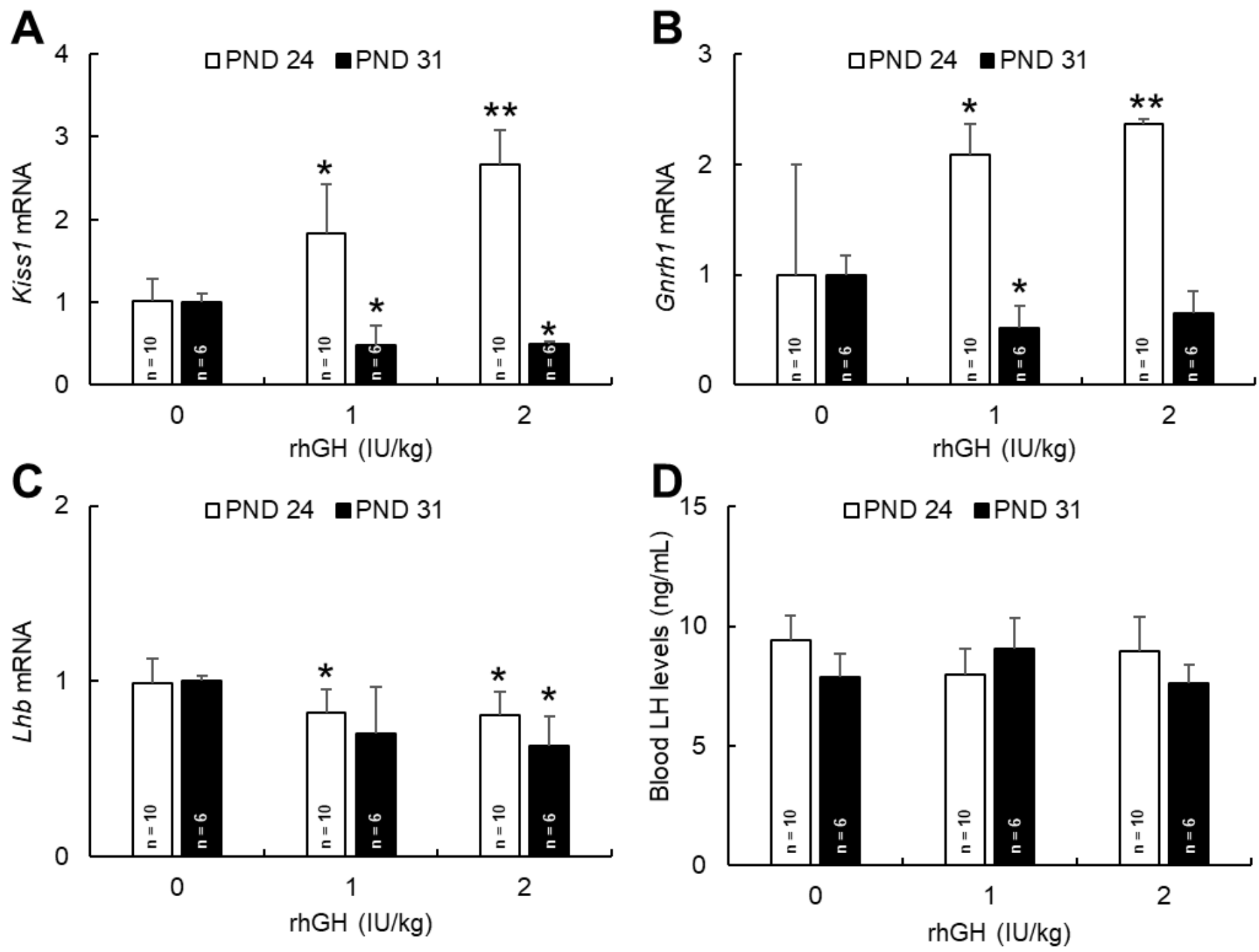

Figure 6

The effects of rhGH on hypothalamic Kiss1 and Gnrh1 and pituitary Lhb mRNA and blood LH levels. (AC) RT-qPCR results for Kiss1 and Gnrh1 mRNA in the hypothalamus and pituitary Lhb mRNA levels on PNDs 24 and 31. Values are presented as the mean \pm SD. (D) ELISA for blood LH levels on PNDs 24 and 31 . Values are presented as the mean \pm SD. *, significantly different from control rats by Student t-testing at $p \otimes 0.05$. 

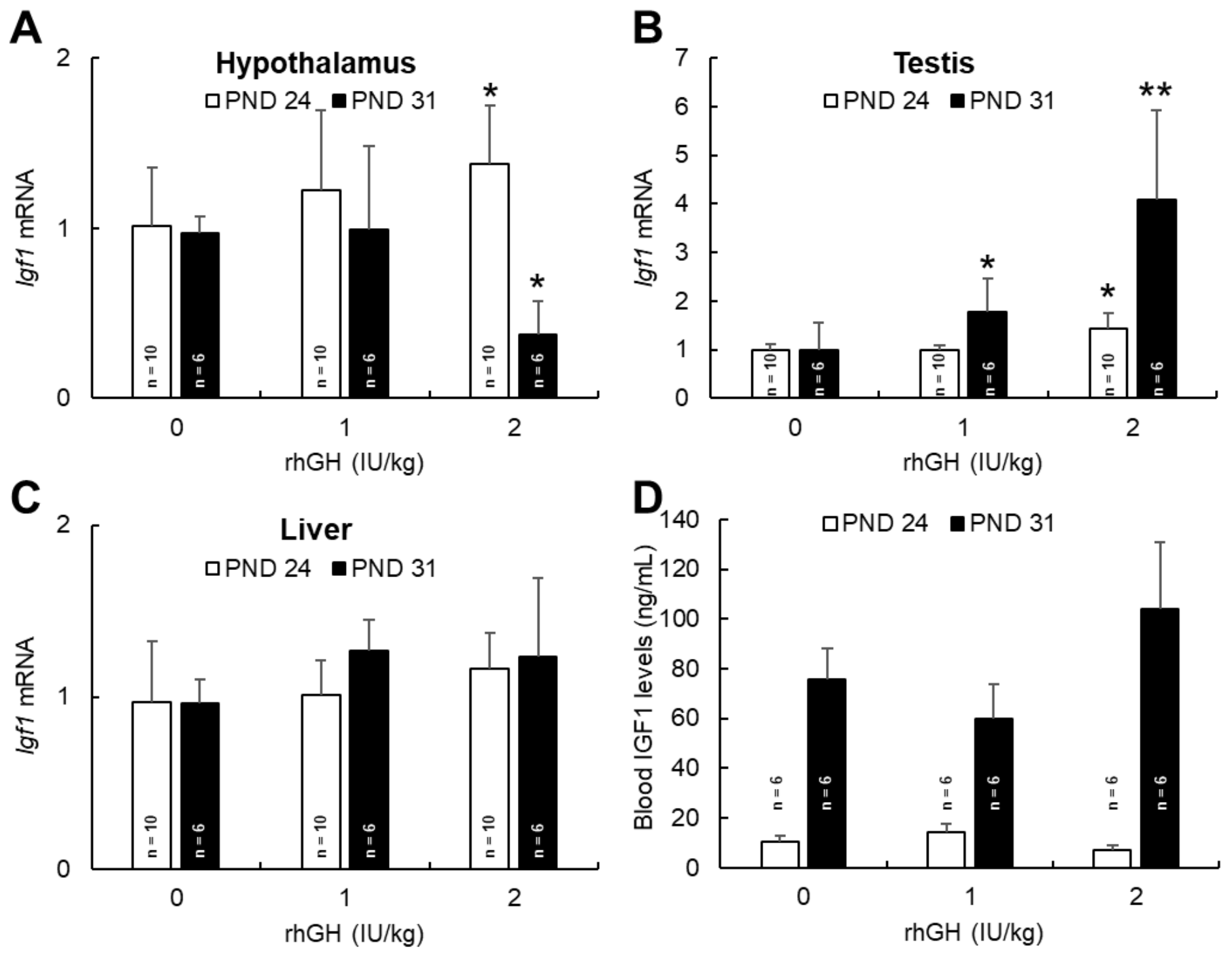

Figure 7

The effects of rhGH on blood IGF1 levels and Igf1 mRNA levels in the hypothalamus, liver, and testes of immature rats on PNDs 24 and 31. (A) Igf1 mRNA levels in the hypothalamus, liver, and testes on PNDs 24 and 31. (B) ELISA for blood IGF1 on PNDs 24 and 31. Values are presented as the mean \pm SD. *, significantly different from control rats by Student t-test at $\mathrm{p} \otimes 0.05$. 

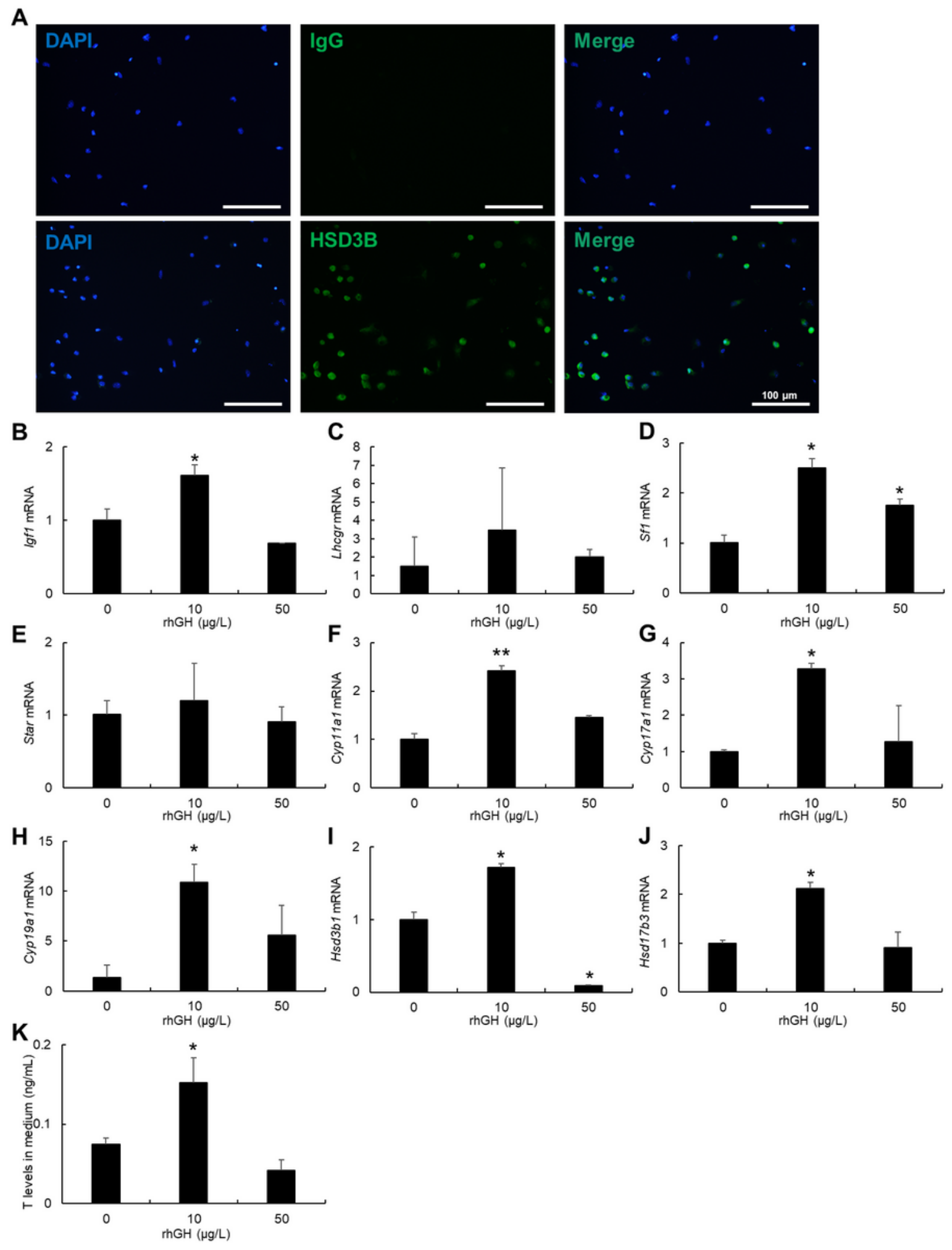

\section{Figure 8}

Changes in steroidogenesis in Leydig cells in vitro. (A) Purity of Leydig cells as shown by immunocytochemistry for HSD3B. (B-J) RT-qPCR results for Igf1, Lhcgr, Sf1, Star, Cyp11a1, Cyp17a1, Cyp19a1, Hsd3b1, and Hsd17b3 mRNA in rhGH-treated Leydig cells in vitro $(n=4)$. (K) ELISA for testosterone in the culture medium of Leydig cells after $48 \mathrm{hrs}$ of rhGH treatment $(n=4)$. Values are presented as the mean \pm SD. *, significantly different from control rats by Student t-test at $p \otimes 0.05$. 


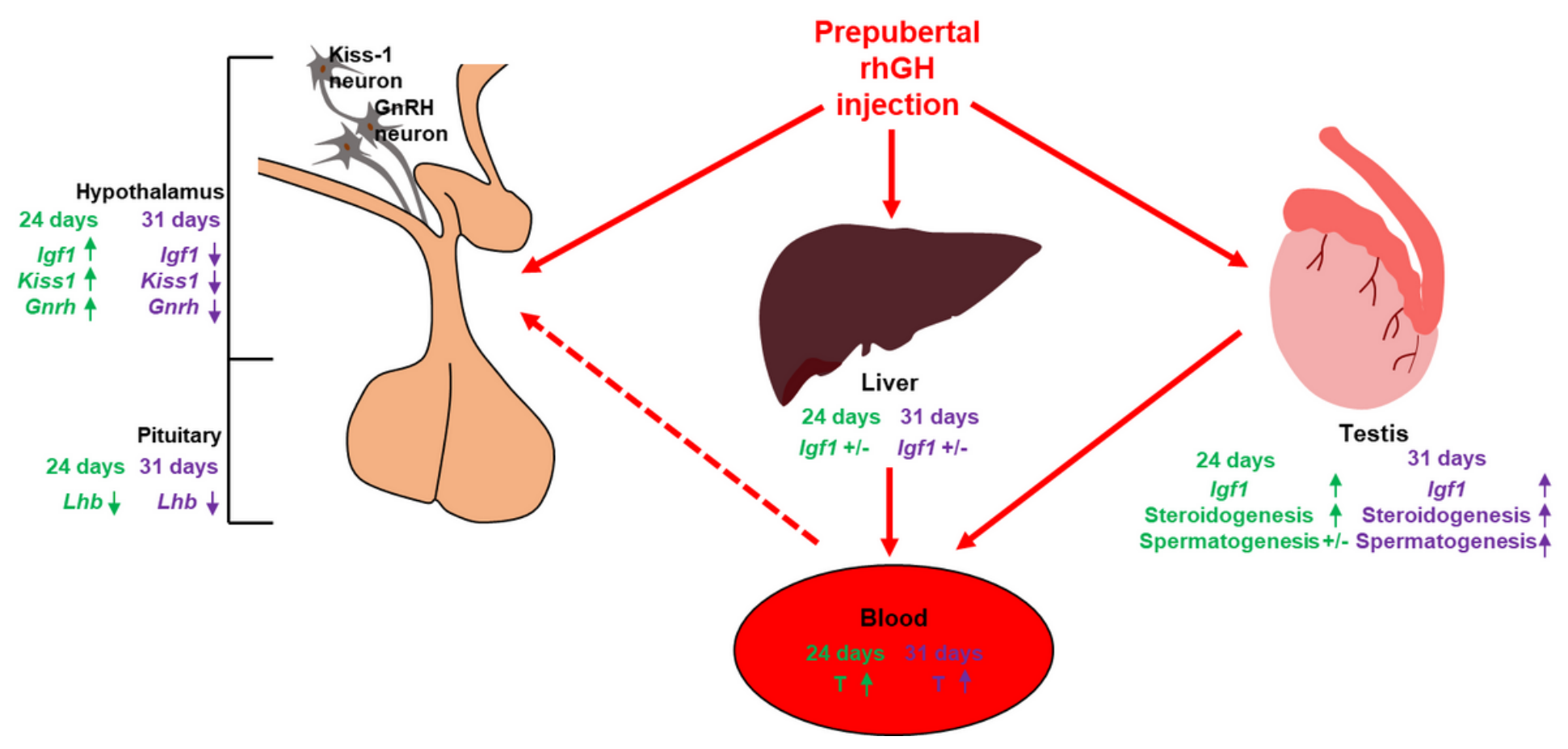

Figure 9

Local increase in IGF1 levels in the testes might be an important mediator for gonadal activation triggered by rhGH in immature rats. Changes in kisspeptin, GnRH, LH, IGF1, and testosterone in the hypothalamus-pituitary-testis axis following daily injections of rhGH from PND 21 to 23 or PND 21 to 30 are summarized. Testicular steroidogenesis, circulating testosterone, and spermatogenesis were higher than control levels in the rhGH rats on PNDs 24 and 31. Hypothalamic Kiss1, Gnrh1, and Igf1 mRNA levels were also higher than control levels in rhGH rats on PND 24, but they became lower than the control levels by PND 31. No significant change in circulating LH levels was observed on PND 24 or 31 in the rhGH rats. In prepubertal male rats, rhGH administration increased testicular but not systemic IGF1 levels, which potentiated testosterone production in Leydig cells and thus increased circulating testosterone, stimulating sexual maturation and spermatogenesis.

\section{Supplementary Files}

This is a list of supplementary files associated with this preprint. Click to download.

- S1.png

- S2.png

- S3.png 